ISSN 2413-0877 Volume 2 (2015) 556

The 3rd International Conference on Biological Science 2013

(The 3rd ICBS-2013)

\title{
EFFECTS OF CHROMIUM ON CHLOROPHYLL-a, CARBOHYDRATE AND PROTEIN CONTENTS IN Tetraselmis sp. (Butcher 1959)
}

\author{
Ernisa Maranatha Nainggolan, Rindra Aryandari, Haikal Prima Fadholi, \\ Andhika Puspito Nugroho, and Eko Agus Suyono \\ Faculty of Biology UniversitasGadjahMada Yogyakarta Indonesia \\ e-mail: aryandaririndra@gmail.com
}

\begin{abstract}
Electroplating and paper industry activities contribute to pollution of chromium $(\mathrm{Cr})$ in aquatic ecosystems. The presence of $\mathrm{Cr}$ can affect the activity of microalgae which play an important role as primary producers in the food chain of ocean ecosystem.Cr was tested on a species ofgreen microalgae, Tetraselmis sp. This microalgae are very abundant in the sea and can accumulate heavy metals, including $\mathrm{Cr}$. Changes in nutrient content in cells of Tetraselmis sp. can affect the productivity of the next trophic level organisms. This research aims to determine effect of $\mathrm{Cr}$ to Chlorophyll-a, carbohydrate and protein content in Tetraselmis sp. The methods of this study include several steps, cultivation with initial density of $40 \times 10^{4} \mathrm{cells} \mathrm{ml}^{-1}$ to log phase, then exposed by $\mathrm{K}_{2} \mathrm{Cr}_{2} \mathrm{O}_{7}$ during 96 hours with concentrations $0 ; 3.2 ; 5.6$, and $10 \mathrm{ppm}$. Cell density was calculated everyday using haemocytometer, observed with microscope and optilab. Chlorophyll-a, carbohydrate and protein were measured by a spectrophotometer on days $0,4,6$ and 8 . Data analysis with ANOVA, the real difference is determined by Dunnet and Duncan Test. The results showed that increasing $\mathrm{Cr}$ concentration causes higher growth inhibition rate of Tetraselmis sp. $\mathrm{IC}_{50}-96$ hours was $2.63 \mathrm{ppm}$ and NOEC value was $<3.2 \mathrm{ppm}$. The content of Chlorophyll-a, showed decrease after $\mathrm{Cr}$ exposure for 96 hours. Carbohydrate content was increased after 72 hours, and then decreased after 96 hours exposure. Protein content increased significantly up to 96 hours.
\end{abstract}

Key words:Tetraselmis sp., Chromium, Toxicity test, Chlorophyll-a.

ISSN 2413-0877 (C) 2015 The Authors.

Published by KnowledgeE Publishing Services This is an open access article under the CC BY-NC-ND license (http://creativecommons.org/licenses/by-nc-nd/4.0)

Selection and Peer-review under responsibility of the 3rd ICBS-2013

Doi http://dx.doi.org/10.18502/kls.v2i1.216 